\title{
Phytoplankton responses to nitrogen and phosphorus enrichment in unproductive Swedish lakes along a gradient of atmospheric nitrogen deposition
}

\author{
Ann-Kristin Bergström*, Anders Jonsson, Mats Jansson \\ Department of Ecology and Environmental Sciences, Umeå University, 90187 Umeå, Sweden
}

\begin{abstract}
Lake sampling and in situ nutrient enrichment enclosure experiments with nitrogen (N) and phosphorus (P) were conducted in unproductive Swedish lakes along a gradient of increasing atmospheric $\mathrm{N}$-deposition. The regional and seasonal patterns of nutrient limitation of phytoplankton were clearly related to the amounts of $\mathrm{N}$-deposition and $\mathrm{N}$-inputs the lakes received. In areas of low $\mathrm{N}$-deposition in northern Sweden, $\mathrm{N}$-limitation of phytoplankton was evident throughout the summer season due to high catchment $\mathrm{N}$-retention and very low dissolved inorganic $\mathrm{N}$ (DIN) inputs during the early summer. High $\mathrm{N}$-deposition in the south was accompanied by high lake DIN-concentrations during the early summer and subsequent P-limitation of phytoplankton. However, P-limitation did not persist over the summer and, as a consequence of a declining DIN-pool, the lakes switched to dual- and co-limitation by $\mathrm{N}$ and $\mathrm{P}$, and then to N-limitation. Generally, the lakes were N-limited rather than P-limited during the summer. We conclude that N-limitation is probably a natural state of the unproductive lakes studied, but P-limitation of variable intensity and duration has been induced by elevated atmospheric N-deposition.
\end{abstract}

KEY WORDS: N-limitation · P-limitation · Phytoplankton · Lakes · N-deposition · Seasonal variation · Nutrients Resale or republication not permitted without written consent of the publisher

\section{INTRODUCTION}

Escalating fossil fuel combustion, agricultural intensification, and forestry fertilizer applications (Galloway \& Cowling 2002) have led to an almost 10-fold increase in anthropogenic nitrogen (N) emissions during the 20th century. Furthermore, current anthropogenic contributions to the global $\mathrm{N}$-cycle are estimated to be of the same magnitude as natural rates of N-mobilization (Steffen et al. 2004), resulting in a large-scale alteration of the global N-cycle (Steffen et al. 2004). Nemissions can be transported long distances and affect aquatic environments far from their sources (Holland et al. 2005). Debates concerning large-scale aquatic Neutrophication have mainly focused on coastal marine systems (Vitousek et al. 1997, Howarth \& Marino 2006), while lakes have been largely neglected, probably because production in lakes has generally been considered to be phosphorus (P)-limited (Kalff 2002).
However, in the 1990s the P-limitation paradigm (Kalff 2002) was questioned after evidence indicated that lake phytoplankton can be primarily or co-limited by $\mathrm{N}$ (Elser et al. 1990).

The possibility that amelioration of N-limitation by $\mathrm{N}$-deposition may have profound effects was subsequently raised by Bergström et al. (2005) and Bergström \& Jansson (2006), who showed that N-deposition had caused large-scale eutrophication of unproductive lakes across substantial areas of Europe and North America. In addition, N-limitation of phytoplankton was found in regions with low rates of $\mathrm{N}$-deposition $\left(<250 \mathrm{~kg} \mathrm{~N} \mathrm{~km}^{-2} \mathrm{yr}^{-1}\right)$, while higher rates $(\geq 500 \mathrm{~kg} \mathrm{~N}$ $\mathrm{km}^{-2} \mathrm{yr}^{-1}$ ) had caused increases in lake inorganic $\mathrm{N}$ concentrations and, consequently, eutrophication. The cited authors suggested that many unproductive lakes in the northern hemisphere are (and probably were for a long time) naturally N-limited, but that P-limitation has resulted in many cases from alterations in the bal- 
ance between $\mathrm{N}$ and $\mathrm{P}$ through increased anthropogenic N-inputs (Bergström \& Jansson 2006). These suggestions are also supported by paleolimnological evidence from the Colorado Front Range (Baron et al. 2000, Wolfe et al. 2001, 2002) and the eastern Canadian Arctic (Wolfe et al. 2006), indicating that enhanced $\mathrm{N}$-deposition since the mid-20th century has increased productivity and caused changes in phytoplankton compositions favoring more mesotrophic species.

However, the conclusions in the studies presented by Bergström et al. (2005) and Bergström \& Jansson (2006) were based on the indirect evidence of a correlation between the phytoplankton biomass to total phosphorus ratio (chl a: $\mathrm{P}_{\text {Tot }}$ ) and rates of $\mathrm{N}$-deposition. Furthermore, the background data were mostly averages obtained from a few samples collected during the summer, and it was also not clear whether nutrient limitation was imposed by a single nutrient during the entire summer season, or whether shifts in nutrient ( $\mathrm{N}$ or $\mathrm{P}$ ) limitation occurred. Hence, the hypothesis of induced P-limitation lacked experimental support, and the effect of this factor in lakes subjected to atmospheric N-deposition during the summer was unknown.

Therefore, to test the hypothesis and examine the effects of $\mathrm{N}$-deposition in more detail, we first examined the mid-summer nutrient limitation of phytoplankton by conducting nutrient enrichment experiments in unproductive lakes along an N-deposition gradient in Sweden, and then investigated seasonal variations in nutrient limitation using a subset of lakes

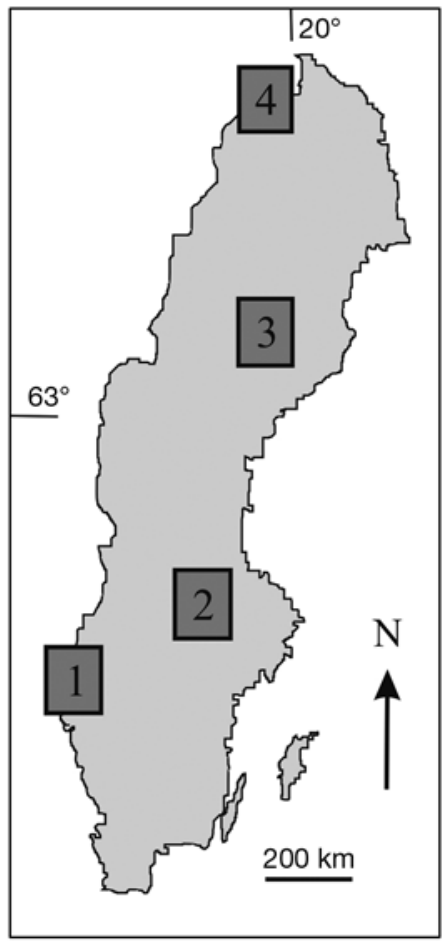

Fig. 1. The Swedish regions investigated in the present study investigated in the nutrient enrichment study. We hypothesized that lakes receiving low atmospheric Ndeposition are primarily $\mathrm{N}$-limited during the summer, while increases in $\mathrm{N}$-deposition rates will shift lakes to being primarily P-limited during the summer.

\section{MATERIALS AND METHODS}

Study area. We sampled lakes and performed enrichment experiments along a roughly north-south axis (with an associated gradient in rates of $\mathrm{N}$-deposition, ranging from 100 to $1000 \mathrm{~kg} \mathrm{~N} \mathrm{~km}^{-2} \mathrm{yr}^{-1}$ ) in 4 regions of boreal Sweden (Fig. 1) during the summers of 2004 to 2006. The influence of agricultural activities and sewage-water inputs on the studied lakes is minor. Thus, apart from liming (which occurs in Regions 1 to 3), the only significant anthropogenic influences are from forestry (which is performed at similar intensities throughout the country) and atmospheric deposition.

Experiments and lake sampling. Nutrient enrichment experiments were initially performed during 2004 and 2005 in 11 or 12 lakes per region in late July to early August (Region 1: July 29-August 4, 2005; Region 2: July 20-23, 2005; Region 3: August 4-7, 2004; Region 4: July 27-29, 2004). These experiments were performed to characterize the mid-summer nutrient limitation of phytoplankton in each region. A second set of experiments was conducted in 2006 in 3 to 4 lakes from each region (included in the 2004 and 2005 experiments) to monitor the seasonal variations in nutrient limitation. These experiments were carried out on 2 or 3 different occasions during the summer (Region 1: May 5-8, June 8-11, July 25-28; Region 2: May 10-13, June 13-16, July 30-August 2; Region 3: May 29-June 1, August 8-11; Region 4: June 12-15, July 28-31). Lakes in Regions 1 and 2 were sampled 3 times because in Sweden summer is longer in the south than in the north (Raab \& Vedin 1995).

Initially, temperature and conductivity profiles were measured to determine stratification conditions. All the lakes from Regions 1 to 3 were stratified (depths between 3 and $6 \mathrm{~m}$ ), while in Region 4 most ( 8 out of 12) of the lakes were unstratified. Water was then pumped from 1 to $2 \mathrm{~m}$ depth (i.e. from the trophogenic layer of the epilimnion or, in unstratified lakes, the surface layers) through a filter (50 $\mu \mathrm{m}$ mesh size) to remove large zooplankton and, hence, minimize grazing. The water was collected in 201 transparent lowdensity polyethylene (LDPE) containers (Cole-Parmer) with $80 \%$ ambient solar irradiance (photosynthetically active radiation, PAR) transmittance. Nutrients were added to the containers to increase the concentrations of $\mathrm{N}$ by $1 \mathrm{mg} \mathrm{l}^{-1}$ and/or the concentrations of $\mathrm{P}$ by $100 \mu \mathrm{g} \mathrm{l}^{-1}$ (molar N:P ratio, 23:1) according to treat- 
ment. $\mathrm{N}$ was added as $\mathrm{NH}_{4} \mathrm{NO}_{3}$ and $\mathrm{P}$ as $\mathrm{KH}_{2} \mathrm{PO}_{4}$ (Jansson et al. 1996), and overall there were 4 separate treatments: no addition (control, C), N-addition (N), Paddition $(\mathrm{P})$, and $\mathrm{N}$ - plus $\mathrm{P}$-addition $(\mathrm{N}+\mathrm{P})$. There were 3 replicates of each treatment per lake, and the containers were incubated in the lakes at $1.5 \mathrm{~m}$ depth for $4 \mathrm{~d}$ in each year, except in 2006 (this duration was selected after a test experiment, performed over 2 to $10 \mathrm{~d}$ in one of the lakes in Region 4 during 2003, showed that nutrient-mediated increases in phytoplankton biomass virtually ceased after 3 to $4 \mathrm{~d}$; data not shown). After incubation, water samples were taken from each container and analyzed for chlorophyll a (chl a). The procedure was similar each year, although the containers were only incubated for $3 \mathrm{~d}$ in 2006.

In addition, during each experiment water samples were taken from the epilimnion at $1.5 \mathrm{~m}$ depth with a Ruttner sampler (2 1) for analyses of water chemistry variables and chl $a$. The light conditions in the containers and the mixed layer of the lakes were calculated following Ramberg (1979) using: mean daily incident PAR ( $\mu \mathrm{mol} \mathrm{m} \mathrm{m}^{-2} \mathrm{~s}^{-1}$ ) data obtained from the Swedish Meteorological and Hydrological Institute (SMHI) (www.smhi.se), the depths of the mixed layers (m), and diffuse light attenuation coefficients $\left(k_{\mathrm{d}}\right)$ calculated from lake dissolved organic carbon (DOC) concentrations (Bukaveckas \& Robbins-Forbes 2000).

Analyses of nutrient enrichment experiments. Spatial and seasonal variations in nutrient limitation were evaluated by measuring chl a responses in the nutrient enrichment enclosure experiments. For each specific lake experiment, 1-way ANOVAs, with Dunnett's post hoc test against a single control group $(\mathrm{p}<0.05)$, were used to examine for significantly higher values in fertilized relative to untreated enclosures (i.e. controls). These analyses were performed on log-transformed data. One-way ANOVAs, with Dunnett's post hoc test against a single control group ( $p<0.05$ ), were also performed on pooled data from each specific region and time period. In these analyses, the data from each lake experiment were first normalized [(chl a/mean chl $\left.a_{\text {experiment }}\right)-\left(\mathrm{SD}\right.$ chl $\left.\left.a_{\text {experiment }}\right)\right]$ to reduce variance between lake experiments, and then log-transformed to obtain a quasi-normal distribution, satisfying the requirements of the subsequent analyses. The different types of nutrient limitation were defined as: N-limitation, which shows a significantly greater response in chl a compared to the control after N-addition, and P-limitation, which shows a significantly greater response in chl a compared to the control after Paddition. Dual limitation by $\mathrm{N}$ and $\mathrm{P}$ was equated to a significantly higher response in chl a relative to controls when both $\mathrm{N}$ - and P-additions alone led to increased chl a (Jansson et al. 2006). Co-limitation by $\mathrm{N}$ and $\mathrm{P}$ was equated with an increase in the $\mathrm{N}+\mathrm{P}$ - treatment relative to the control (Jansson et al. 2006) when there was no response to $\mathrm{N}$ added alone or to $\mathrm{P}$ added alone.

The mean degree of $\mathrm{N}$ - and P-limitation was also estimated for each of the regions during the summer of 2006 by dividing the mean summer chl a concentrations in $\mathrm{N}$ - and P-treated enclosures, respectively, by the mean concentrations in the corresponding controls. The mean degree of $\mathrm{N}$ - and P-limitation during the summer was then related to the annual wet dissolved inorganic N-deposition (DIN-deposition).

Analyses of lake water samples. $\mathrm{pH}$ was measured in the laboratory using an Orion portable meter (Model 230). Samples to be used for ammonia $\left(\mathrm{NH}_{4}\right)$ and nitrate $\left(\mathrm{NO}_{3}\right)$ analyses were filtered (using $0.45 \mu \mathrm{m}$ Sartorius cellulose acetate filters) then frozen and stored until analysis, while samples to be used for total nitrogen $\left(\mathrm{N}_{\text {Tot }}\right)$ and phosphorus $\left(\mathrm{P}_{\text {Tot }}\right)$ were frozen and stored unfiltered. The contents of these nutrients in the samples were subsequently analyzed at the Evolutionary Biology Center (EBC) Limnology Section, Uppsala, Sweden, following procedures of Bergström \& Jansson (2000). Samples to be used for DOC determinations were filtered using precombusted GF/F filters $(0.7 \mu \mathrm{m}$, $2 \mathrm{~cm}$ diameter), and the resulting filtrates were then stored in a freezer until their DOC contents were determined, after Sobek et al. (2003), using a Shimadzu TOC 5000 at the EBC for samples taken during 2004 and 2005, and a Shimadzu TOC VCPH at the Abisko Scientific Research Station, Abisko, Sweden for samples taken in 2006. In addition, known volumes of samples to be used for chl a determinations (both lake and experiment samples) were GF/F filtered $(0.7 \mu \mathrm{m}$, $4.25 \mathrm{~cm}$ diameter) in the dark, and the filters were then stored in a freezer until chlorophyll was extracted from them (within 1 mo of sampling) by placing each filter in $10 \mathrm{ml}$ of ethanol for $24 \mathrm{~h}$ in the dark and at room temperature. A luminescence spectrofluorometer (Perkin Elmer, LS 55), was then used to estimate the chl a contents of the extracts by measuring emissions at $673 \mathrm{~nm}$ following excitation by $433 \mathrm{~nm}$ light. Extracted chlorophyll was not corrected for pheophytin interference using acidification.

Atmospheric deposition. Measurements of wet bulk atmospheric DIN-deposition were obtained from the Swedish Environmental Research Institute (IVL) (www.ivl.se) for each sampling year (Bergström et al. 2005). In addition, annual wet DIN-deposition rates for 2004 to 2006 were estimated using data from monitoring stations situated close to the studied regions. We also estimated deposition between January and July in 2004 and 2005 for each region, and the wet DINdeposition in each region during the period before the sampling dates, i.e. January to May (only Regions 1 and 2), January to June, and January to July, in 2006. 
DIN-concentrations in the Swedish Monitoring Program of streams and lakes. DIN-estimates for the lakes in each of the regions were obtained using data gathered by the Swedish Reference Monitoring Program for running waters and lakes, provided by the Department of Environmental Assessment Analyses, Swedish University of Agriculture Sciences, Uppsala, Sweden (www.ma.slu.se). Monthly DINconcentration data were collected for small streams and lakes (lake surface area: 0.06 to $2.0 \mathrm{~km}^{2}$ ) from forested catchments in each of the 4 regions. The stream and lake locations chosen had very small upstream lakes (or none) in their respective drainage areas, and all chosen lakes had an inlet stream. The collated data spanned different time periods, from just 1 yr to 23 consecutive years. Data for 3 streams (828 samples) and 5 lakes (519 samples) were collated for Region 1, 5 streams (921 samples) and 8 lakes (764 samples) for Region 2, 9 streams (1408 samples) and 7 lakes (682 samples) for Region 3, and 4 streams (799 samples) and 5 lakes (338 samples) for Region 4. Monthly DIN means and standard deviations were calculated for the streams and lakes from each region.

\section{RESULTS}

\section{Lake characteristics}

Physical, chemical and biological characteristics of the lakes sampled are given in Tables $1 \& 2$. The surface areas of the lakes used in the enrichment experiments ranged between 0.02 and $2.48 \mathrm{~km}^{2}$. The annual wet DIN-deposition rates decreased across the gradient south to north; from $800 \mathrm{~N} \mathrm{~km}^{-2} \mathrm{yr}^{-1}$ in Region 1 (southernmost) to $<100 \mathrm{~kg} \mathrm{~N} \mathrm{~km}{ }^{-2} \mathrm{yr}^{-1}$ in Region 4 (northernmost). Lake conductivity also declined south to north, from 60 to $32 \mu \mathrm{S} \mathrm{cm}{ }^{-1}$. In addition, lake water temperatures in Region 4 were somewhat lower, while $\mathrm{pH}$ measurements were higher, on average, than in the other regions. Lakes were most humic in Region 3 (mean DOC: $12.8 \mathrm{mg} \mathrm{l}^{-1}$ ), followed by Regions 2 $\left(8.4 \mathrm{mg} \mathrm{l}^{-1}\right), 1\left(7.6 \mathrm{mg} \mathrm{l}^{-1}\right)$, and $4\left(6.1 \mathrm{mg} \mathrm{l}^{-1}\right)$. The highest mean $\mathrm{P}_{\text {Tot }}$ concentration was also found in Region 3, which was unsurprising since the mean DOC was highest in this region (Meili 1992). Mean $\mathrm{N}_{\text {Tot }}$ concentrations ranged between 217 and $280 \mu \mathrm{g} \mathrm{l}^{-1}$, and DINconcentrations ranged between 9 and $26 \mu \mathrm{g} \mathrm{l}^{-1}$. The phytoplankton biomass (expressed as chl a) was

Table 1. Characteristics of the lakes sampled from late July to early August during 2004 (Regions 3 and 4) and 2005 (Regions 1 and 2). Values presented as averages $\pm \mathrm{SD}_{i} 12$ lakes were studied in each region (11 in Region 2). Cond.: conductivity; DOC: dissolved organic carbon; $\mathrm{N}_{\text {Tot }}$ : total nitrogen; DIN: dissolved inorganic nitrogen; $\mathrm{P}_{\text {Tot: }}$ total phosphorus; chl a: chlorophyll a; DIN ${ }_{\text {dep1 }}$ : wet DIN-deposition

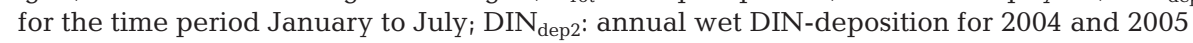

\begin{tabular}{|c|c|c|c|c|c|c|c|c|c|c|c|c|c|}
\hline Region & $\begin{array}{l}\text { Lake } \\
\text { area }\left(\mathrm{km}^{2}\right)\end{array}$ & $\begin{array}{l}\text { Temp. } \\
\left(\mathrm{C}^{\circ}\right)\end{array}$ & $\begin{array}{l}\text { Cond. } \\
\left(\mu \mathrm{S} \mathrm{cm}^{-1}\right)\end{array}$ & $\mathrm{pH}$ & DOC & $\begin{array}{c}\mathrm{N}_{\text {Tot }} \\
\left(\mathrm{mg} \mathrm{l}^{-1}\right)\end{array}$ & DIN & $\begin{array}{c}\mathrm{P}_{\text {Tot }} \\
\left({\left.\operatorname{\mu g~l} \mathrm{l}^{-1}\right)}\right.\end{array}$ & $\begin{array}{l}\text { DIN: } \\
\mathrm{P}_{\text {Tot }}\end{array}$ & $\begin{array}{c}\mathrm{Chl} \mathrm{a} \\
\left(\mu \mathrm{g} \mathrm{l}^{-1}\right)\end{array}$ & $\begin{array}{l}\text { Chl a: } \\
\mathrm{P}_{\text {Tot }}\end{array}$ & $\begin{array}{l}\mathrm{DIN}_{\mathrm{dep} 1} \\
\left(\mathrm{~kg} \mathrm{~N} \mathrm{~km}^{-}\right.\end{array}$ & $\begin{array}{l}\mathrm{DIN}_{\mathrm{dep} 2} \\
\left.-{ }^{-2} \mathrm{yr}^{-1}\right)\end{array}$ \\
\hline 1 & $0.41 \pm 0.64$ & $19.3 \pm 0.9$ & $60 \pm 12$ & $6.5 \pm 0.5$ & $7.6 \pm 2.8$ & $264 \pm 48$ & $11 \pm 6$ & $10 \pm 7$ & $1.7 \pm 1.3$ & $3.7 \pm 4.3$ & $0.38 \pm 0.25$ & 492 & 800 \\
\hline 3 & $0.49 \pm 0.41$ & $21.4 \pm 1.0$ & $34 \pm 5$ & $6.2 \pm 0.4$ & $12.8 \pm 3.4$ & $247 \pm 45$ & $20 \pm 8$ & $18 \pm 5$ & $1.2 \pm 0.5$ & $2.9 \pm 2.0$ & $0.16 \pm 0.10$ & 142 & 195 \\
\hline 4 & $0.17 \pm 0.16$ & $15.7 \pm 1.2$ & $32 \pm 17$ & $7.0 \pm 0.3$ & $6.1 \pm 2.4$ & $217 \pm 119$ & $26 \pm 22$ & $10 \pm 4$ & $2.9 \pm 2.7$ & $1.6 \pm 0.9$ & $0.16 \pm 0.09$ & 52 & 88 \\
\hline
\end{tabular}

Table 2. Characteristics of the lakes included in the 2006 seasonal study. Time periods: Regions 3 and 4, Jun = early summer, Jul/Aug =

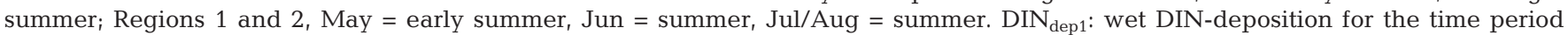

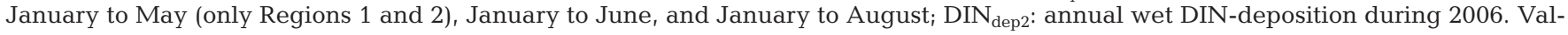
ues presented as averages \pm SD; 3 lakes were sampled in Region 4, while 4 lakes were sampled in the other regions. Other abbrevations, see Table 1

\begin{tabular}{|c|c|c|c|c|c|c|c|c|c|c|c|c|c|}
\hline Region & Time & $\begin{array}{l}\text { Temp. } \\
\left(\mathrm{C}^{\circ}\right)\end{array}$ & $\begin{array}{l}\text { Cond. } \\
\left(\mu \mathrm{S} \mathrm{cm}^{-1}\right)\end{array}$ & $\mathrm{pH}$ & $\begin{array}{c}\text { DOC } \\
\left(\mathrm{mg} \mathrm{l}^{-1}\right)\end{array}$ & $\mathrm{N}_{\text {Tot }}$ & $\begin{array}{c}\text { DIN } \\
\left(\mu \mathrm{gl}^{-1}\right)\end{array}$ & $\mathrm{P}_{\text {Tot }}$ & $\begin{array}{l}\text { DIN: } \\
\mathrm{P}_{\text {Tot }}\end{array}$ & $\begin{array}{c}\mathrm{Chl} a \\
\left(\mu \mathrm{g} \mathrm{l}^{-1}\right)\end{array}$ & $\begin{array}{l}\text { Chl a: } \\
\mathrm{P}_{\text {Tot }}\end{array}$ & $\begin{array}{l}\mathrm{DIN}_{\mathrm{dep} 1} \\
\text { (kg N km}^{-}\end{array}$ & $\begin{array}{l}\mathrm{DIN}_{\mathrm{dep} 2} \\
\left.-{ }^{-2} \mathrm{yr}^{-1}\right)\end{array}$ \\
\hline \multirow[t]{2}{*}{1} & May & $11.8 \pm 1.3$ & $51 \pm 8$ & $6.2 \pm 0.7$ & $7.9 \pm 2.7$ & $185 \pm 7$ & $30 \pm 13$ & $6.0 \pm 0.7$ & $5.2 \pm 2.8$ & $1.3 \pm 0.6$ & $0.20 \pm 0.09$ & 320 & 920 \\
\hline & Jul/Aug & $24.5 \pm 1.4$ & $54 \pm 11$ & $6.6 \pm 0.7$ & $7.9 \pm 2.2$ & $159 \pm 17$ & $11 \pm 7$ & $6.3 \pm 0.4$ & $1.8 \pm 1.2$ & $1.4 \pm 0.3$ & $0.22 \pm 0.03$ & 478 & \\
\hline \multirow[t]{2}{*}{2} & May & $15.1 \pm 0.8$ & $42 \pm 9$ & $6.0 \pm 0.3$ & $10.2 \pm 1.9$ & $210 \pm 56$ & $25 \pm 16$ & $8.1 \pm 1.5$ & $3.0 \pm 1.7$ & $2.1 \pm 0.9$ & $0.25 \pm 0.07$ & 278 & 670 \\
\hline & Jun & $23.5 \pm 1.0$ & $40 \pm 9$ & $6.3 \pm 0.1$ & $10.4 \pm 1.6$ & $200 \pm 33$ & $12 \pm 7$ & $8.3 \pm 1.5$ & $1.3 \pm 0.7$ & $2.3 \pm 1.4$ & $0.26 \pm 0.14$ & 308 & \\
\hline 3 & Jul/Aug & $21.3 \pm 0.9$ & $30 \pm 1.0$ & $6.6 \pm 0.4$ & $9.4 \pm 2.4$ & $147 \pm 15$ & $7 \pm 3$ & $9.5 \pm 1.2$ & $0.8 \pm 0.3$ & $2.4 \pm 0.7$ & $0.26 \pm 0.08$ & 151 & \\
\hline \multirow[t]{2}{*}{4} & Jun & $10.4 \pm 1.4$ & $14 \pm 6$ & $6.7 \pm 0.3$ & $4.2 \pm 1.1$ & $78 \pm 12$ & $3 \pm 0$ & $6.2 \pm 2.3$ & $0.6 \pm 0.4$ & $1.3 \pm 0.2$ & $0.25 \pm 0.11$ & 11 & 40 \\
\hline & Jul/Aug & $15.4 \pm 0.9$ & $14 \pm 6$ & $6.9 \pm 0.4$ & $4.7 \pm 1.7$ & $93 \pm 28$ & $6 \pm 0$ & $6.1 \pm 2.1$ & $1.0 \pm 0.2$ & $0.7 \pm 0.3$ & $0.12 \pm 0.02$ & 23 & \\
\hline
\end{tabular}


generally low, and the mean decreased across Region 1 to Region 4 (from 3.7 to $1.6 \mu \mathrm{g} \mathrm{l}^{-1}$ ). The mean ratio of chl a: $\mathrm{P}_{\text {Tot }}$ followed the same pattern, decreasing by a factor of about 2.4 across Region 1 to Region 4. Thus, phytoplankton biomass per unit phosphorus was higher in regions with high atmospheric N-deposition.

Both the accumulated N-deposition and the annual wet DIN-deposition decreased across Region 1 to Region 4 in 2006. $\mathrm{P}_{\text {Tot }}$ concentrations were rather stable seasonally, whereas DIN-concentrations varied between regions and over the summer. DIN-concentrations were low over the summer in the northern regions (Regions 3 and 4), and the DIN: $\mathrm{P}_{\text {Tot }}$ ratios varied between 0.3 and 1.3. The highest DIN-concentrations were measured in the southern regions (1 and 2) during the early summer; over the summer these declined, and the DIN: $\mathrm{P}_{\text {Tot }}$ ratios consequently decreased from ca. 5 to 2 in Region 1 and from ca. 3 to 1 in Region 2.

\section{DIN-concentrations in Monitoring Program streams and lakes}

Large changes in the DIN-concentrations of both small streams and lakes were seen over the year. The temporal variations were largest in Regions 1 and 2 (south) (Fig. 2), and the lake DIN-concentrations were strongly correlated with the stream water concentrations $\left(\mathrm{r}^{2}\right.$ values varied from 0.73 to $\left.0.87, \mathrm{p} \leq 0.002\right)$.
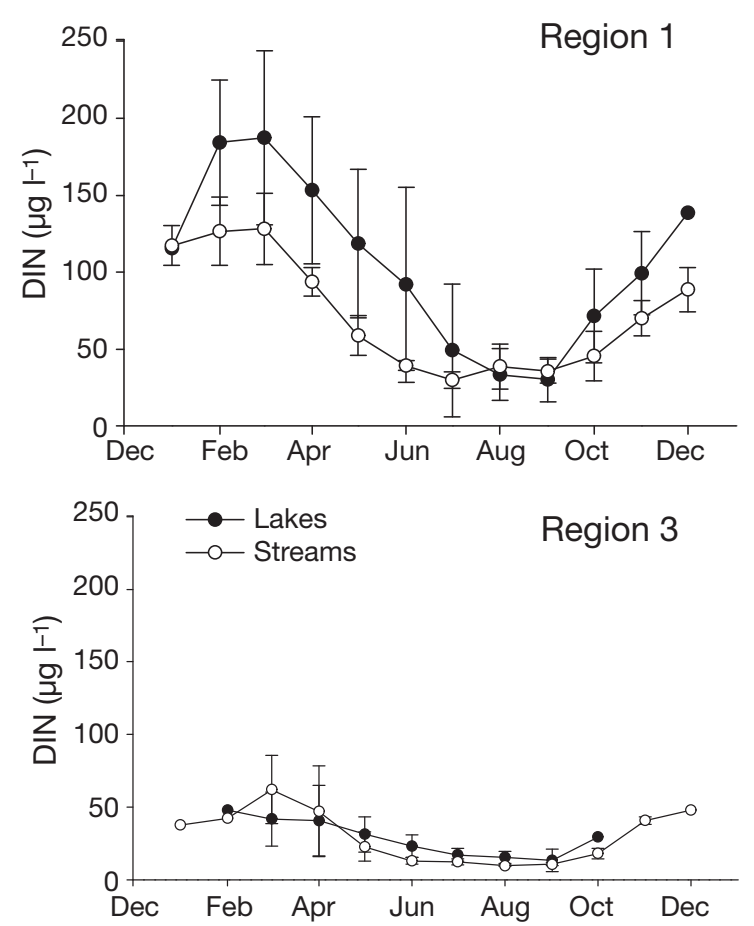

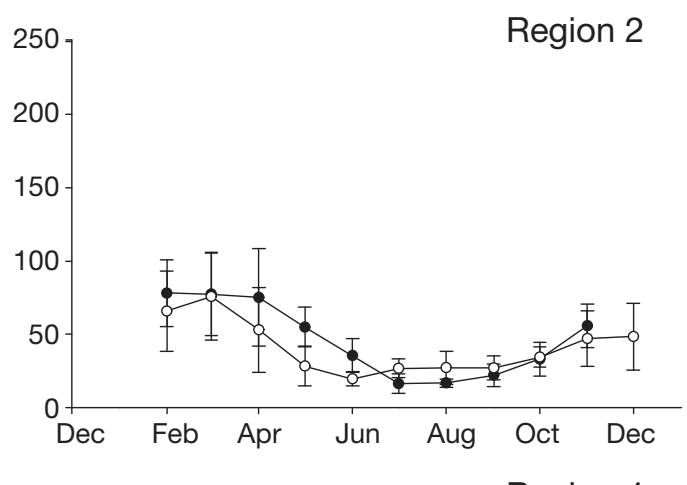

\section{Experiments}

Mean daily light intensities in the experimental containers ranged between 70 and $500 \mu \mathrm{mol} \mathrm{m} \mathrm{m}^{-2} \mathrm{~s}^{-1}$, and in the mixed layers of experimental lakes they ranged between 45 and $400 \mu \mathrm{mol} \mathrm{m}{ }^{-2} \mathrm{~s}^{-1}$. These levels greatly exceeded reported irradiance levels of potential light limitation in phytoplankton $\left(<7 \mu \mathrm{mol} \mathrm{m} \mathrm{m}^{-2} \mathrm{~s}^{-1}\right.$ ) (Koch et al. 2004), implying that the lakes were primarily nutrient limited. The results from the mid-summer nutrient enrichment enclosure experiments of 2004 and 2005 (Fig. 3A) show that chl a concentrations significantly increased $(\mathrm{p}<0.05)$ after $\mathrm{N}+\mathrm{P}$-addition in every lake and region studied (the latter based on 1-way ANOVAs applied to pooled data for each region). In addition, the response of phytoplankton was significantly stronger $(\mathrm{p}<0.05)$ after $\mathrm{N}$-addition alone than after $\mathrm{P}$-addition alone (Fig. 3A,B) Data for individual lakes showed that the phytoplankton biomass was significantly higher $(\mathrm{p}<0.05)$ after $\mathrm{N}$-addition, relative to the control treatment, in 9 lakes out of 12 in Region 4 (Fig. 3B). In the other lakes, phytoplankton were either co-limited (1 lake) or dual-limited (2 lakes). In Region 3, Nlimitation was even more frequent (10 N-limited lakes out of 12 lakes). In Region 2, there was a response to $\mathrm{P}$-addition in 1 lake, but most lakes responded to $\mathrm{N}$ addition (Fig. 3B). In Region 1, two lakes responded to $\mathrm{P}$-addition, although most of the lakes responded to $\mathrm{N}$-addition (Fig. 3B). Therefore, N-limited lakes clearly

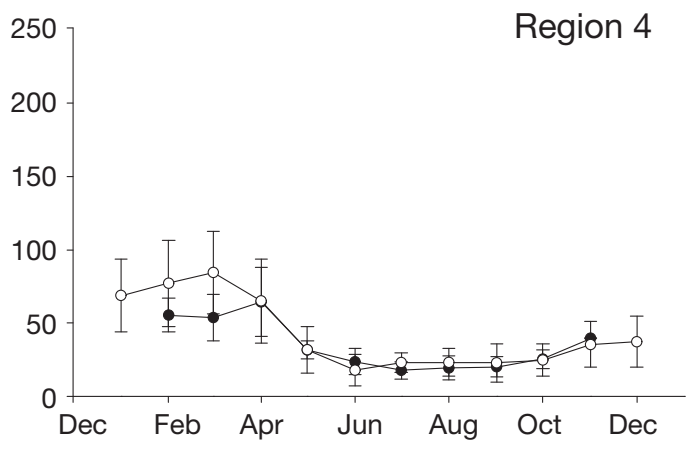

Fig. 2. Mean monthly concentrations of dissolved inorganic nitrogen (DIN) in small headwater streams and lakes in Regions 1 to 4 

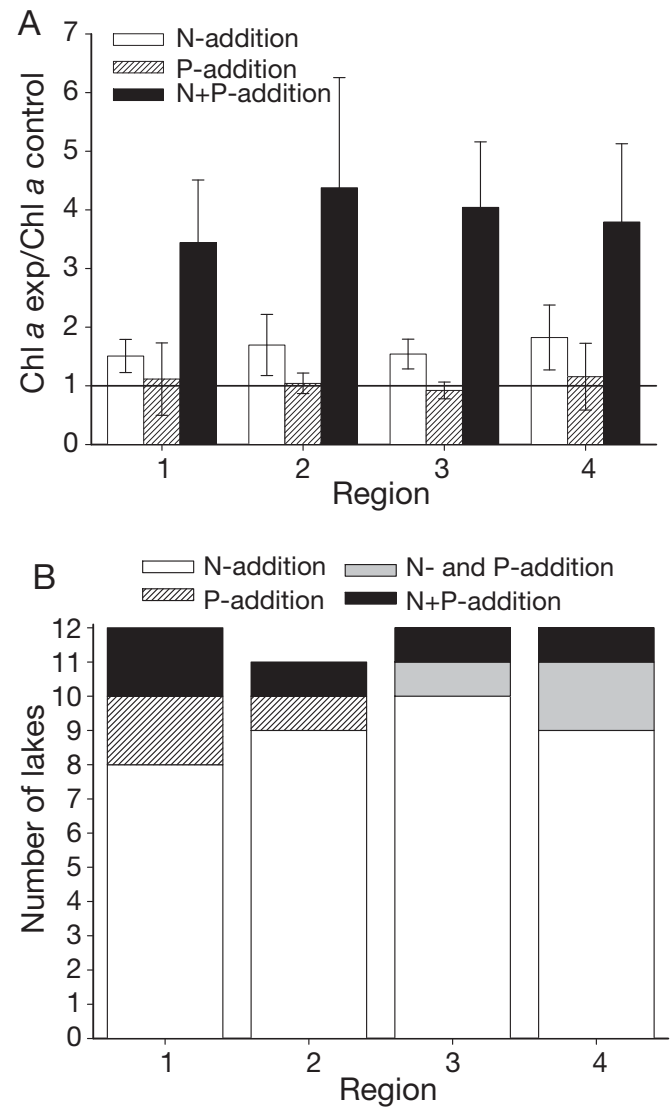

Fig. 3. (A) Average responses $( \pm \mathrm{SD})$ in chl a concentrations relative to corresponding controls in enclosures with different nutrient additions $(\mathrm{N}, \mathrm{P}$, and $\mathrm{N}+\mathrm{P}) ; 12$ lakes were tested in each region (11 in Region 2). (B) Number of lakes showing significant $(\mathrm{p}<0.05)$ positive responses (relative to controls) to the specific additions

represented the majority in all regions during midsummer (Fig. 3A,B).

However, seasonal patterns in nutrient limitation differed between the southern Regions 1 and 2 and the northern Regions 3 and 4, as shown in Fig. 4A,B. When analyzed separately, lakes in Regions 3 and 4 were clearly N-limited throughout the summer, although 1 lake in Region 3 did not respond to any nutrient addition (Fig. 4A,B). In Region 2, the lakes generally switched from P- to N-limitation over the summer (May to July). The pattern was similar in Region 1, but the switch was not as clear, since P-limitation persisted in one lake in June (Fig. 4A). One lake in Region 1 was also co-limited during July. Thus, the switch in nutrient limitation of phytoplankton, from clear P-limitation to clear N-limitation, was more pronounced and occurred earlier in Region 2 than in Region 1 (Fig. 4A,B). Oneway ANOVAs $(p<0.05)$ applied to pooled data for each region and time period revealed that lakes in Regions 3 and 4 were clearly N-limited over summer; lakes in Region 2 switched from P- to N-limitation by
A

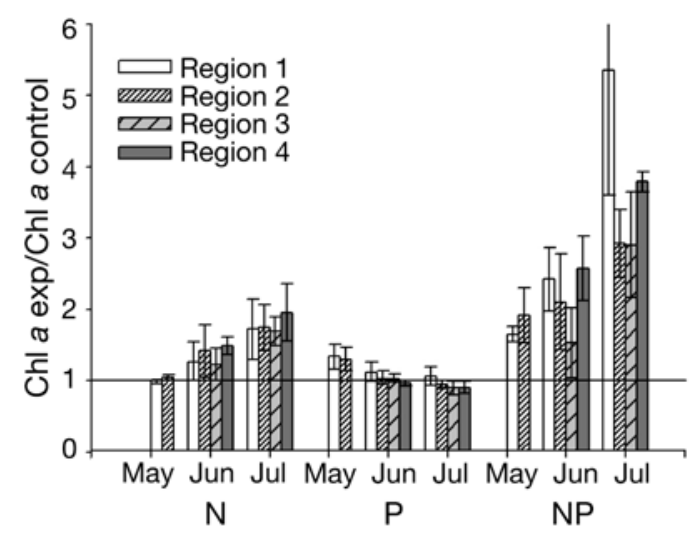

B

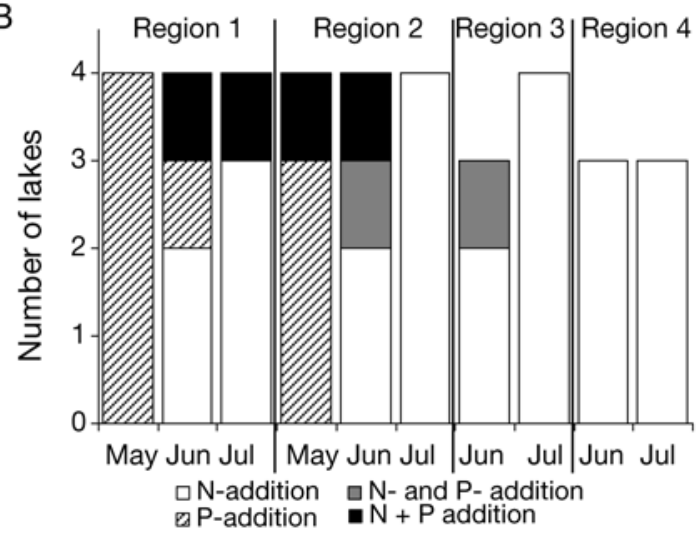

Fig. 4. (A) Average responses $( \pm \mathrm{SD})$ in chl a concentrations relative to corresponding controls in the enclosures with different nutrient additions $(\mathrm{N}, \mathrm{P}$, and $\mathrm{N}+\mathrm{P}$ ) at different times. Experiments were conducted in May, June, and July/August (Jul) in Regions 1 and 2, but only in June and July/August (Jul) in Regions 3 and 4. (B) Number of lakes showing significant $(\mathrm{p}<0.05)$ positive responses (relative to controls) to the specific additions

June, and N-limitation persisted until July; while lakes in Region 1 switched from P-limitation to co- and Nlimitation over the summer. Thus, in all regions, the degree of N-limitation of phytoplankton was enhanced over the summer, whereas the opposite occurred for P-limitation (Fig. 4A). Phytoplankton also became increasingly nutrient limited, since the response to $\mathrm{N}+\mathrm{P}$ addition, relative to the controls, increased over the summer (Fig. 4A).

The degree of $\mathrm{P}$ - and N-limitation relative to the controls was related to the seasonal variation in DIN: $\mathrm{P}_{\text {Tot }}$ ratios over the summer. N-limitation predominated at DIN: $\mathrm{P}_{\text {Tot }}$ ratios $<1.5$, whereas P-limitation dominated at higher ratios (Fig. 5). The mean degree of $\mathrm{N}$ - and $\mathrm{P}$ limitation observed in each region was related to the annual wet DIN-deposition (Fig. 6). In Regions 3 and 4 (low N-deposition), N-limitation was constant throughout the summer, and P did not stimulate phytoplankton development. P-limitation only occurred in Regions 1 

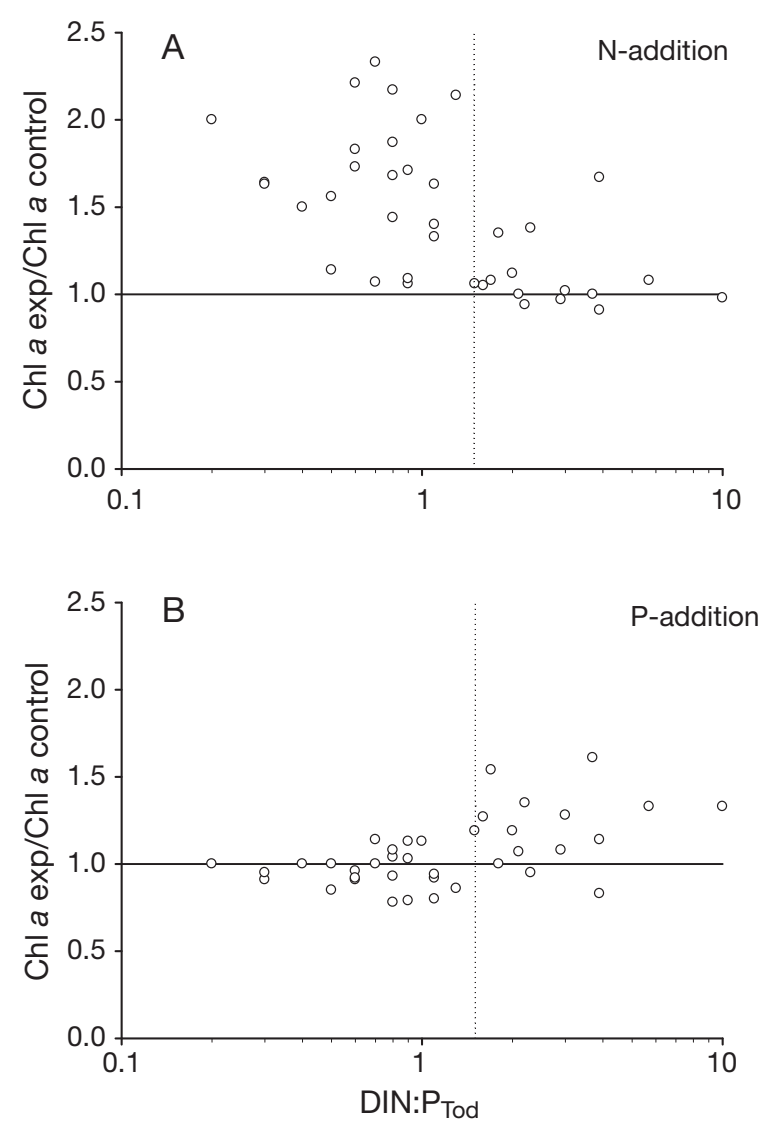

Fig. 5. Relationship between lake DIN: $\mathrm{P}_{\text {Tot }}$ ratios and the chl a concentration responses, relative to controls, in the summer of 2006, to: (A) N-additions and (B) P-additions. Dotted line indicates a DIN: $\mathrm{P}_{\text {Tot }}$ ratio of 1.5

and 2 (high N-deposition), with the mean summer degree of P-limitation highest in Region 1. However, mean summer degrees of $\mathrm{N}$-limitation were still higher than those of P-limitation in Regions 1 and 2 (Fig. 6).

\section{DISCUSSION}

Short-term mesocosm experiments were used to assess regional and seasonal variations in the nutrient limitation of phytoplankton in unproductive Swedish lakes. The experimental results represent snap-shot indices of spatial and temporal changes in the nutrient limitation of natural phytoplankton assemblages, as affected by variations in nutrient loadings and lake $\mathrm{DIN}: \mathrm{P}_{\text {Tot }}$ ratios. This experimental approach, therefore, lacks some ecological realism since, inter alia, it neglects predation (Schindler 1998). The exhaustion of dissolved inorganic carbon (DIC) and nitrogen gas $\left(\mathrm{N}_{2}\right)$ is a potential problem associated with enclosures, since carbon dioxide $\left(\mathrm{CO}_{2}\right)$ and $\mathrm{N}_{2}$ diffusion from the atmosphere are prevented (Schindler 1977). Hence,

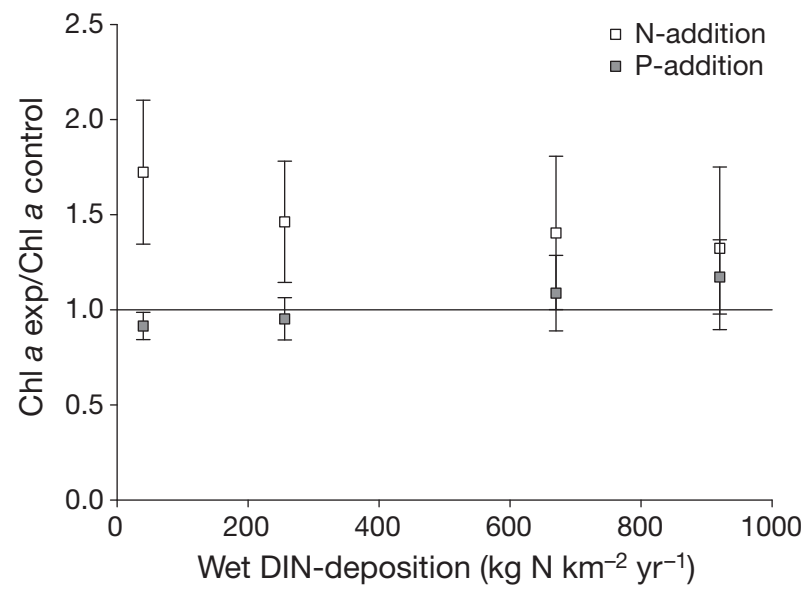

Fig. 6. Relationship between annual wet DIN-depositions and the mean responses in chl a concentrations, relative to controls in the summer of 2006, to $\mathrm{N}$ - and P-additions from Regions 1 to 4 (mean values \pm SD for all experiments)

DIC-concentrations were measured in the enclosures at the beginning and end of the experiments in the lakes with the lowest DIC-concentrations (Region 4). The DIC-concentrations remained at 70 to $100 \%$ of the initial concentrations after 3 to $4 \mathrm{~d}$ incubation. In most of the study lakes the $\mathrm{CO}_{2}$ was a large part of the total DIC and varied between 20 and 100\% (median: $44 \%$ ), as calculated from pH (Table 2; see Wetzel 2001). Tests where net primary production was measured in $\mathrm{N}+\mathrm{P}$ enriched mesocosms during $4 \mathrm{~d}$ in some of the lakes showed that estimated $\mathrm{CO}_{2}$ consumption was well below the $\mathrm{CO}_{2}$ pool at the start of the experiment (A.K. Bergström unpubl. data). Hence, we consider that biomass development and phytoplankton production were not limited by DIC-exhaustion in the enclosures. Furthermore, it is very unlikely that $\mathrm{N}_{2}$-fixation would ever be limited by $\mathrm{N}_{2}$ in the enclosures, since: surface water $\mathrm{N}_{2}$ concentrations vastly exceed the halfsaturation constant for N-uptake by phytoplankton (Bryhn \& Blenckner 2007); the planktonic N-fixation rates reported for oligo- to mesotrophic lakes are low (Wetzel 2001); and the incubation times were short, 3 to $4 \mathrm{~d}$. Consequently, the results from our enrichment enclosure experiments can be used to assess nutrient limitation of phytoplankton.

The regional differences in nutrient limitation of phytoplankton in unproductive Swedish lakes were related to atmospheric N-deposition and lake DINconcentrations. Phytoplankton were N-limited in the northern lakes subject to low N-deposition (Regions 3 and 4), while in the southern lakes (Regions 1 and 2), higher $\mathrm{N}$-deposition was accompanied by increased lake DIN-concentrations and a switch from N- to Plimitation of phytoplankton. These findings are consis- 
tent with previously reported results based on monitoring data, which also showed regional differences in nutrient limitation related to $\mathrm{N}$-deposition (Bergström et al. 2005).

There were clear regional differences in the observed changes in nutrient limitation over the summer season. Whereas N-limitation persisted over the entire summer in lakes in northern Sweden (Regions 3 and 4), lakes were generally P-limited for a short period during the early summer in southern Sweden (Regions 1 and 2). Furthermore, the degrees of N- and P-limitation were directly related to the DIN: $\mathrm{P}_{\text {Tot }}$ ratios. During the early summer, the DIN pool declined in Regions 1 and 2, which contributed to decreases in the DIN: $\mathrm{P}_{\text {Tot }}$ ratios and a switch from P-limitation to dual- (N- and $\mathrm{P}-)$, Co- $(\mathrm{N}+\mathrm{P})$, and N-limitation of phytoplankton over the summer season. Phytoplankton were generally $\mathrm{N}$ limited when DIN: $\mathrm{P}_{\text {Tot }}$ ratios were $<1.5$, in approximate accordance with observations in unproductive lakes in the USA (Morris \& Lewis 1988, Axler et al. 1994).

Nutrient limitation was not only related to N-deposition, but also to differences in climatic and hydrological parameters. In southern Sweden (Regions 1 and 2), high winter discharge due to rain events (Raab \& Vedin 1995), together with high N-deposition and Nsaturation of catchments (Binkley \& Högberg 1997), led to high DIN-concentrations in lakes during winter (November to April) and early summer. Conversely, the hydrology in northern Sweden (Regions 3 and 4) is characterized by low winter discharge and pronounced spring floods in May/early June following snow melt (Raab \& Vedin 1995). These conditions, together with low $\mathrm{N}$-deposition and $\mathrm{N}$-deficiency in the catchments (Binkley \& Högberg 1997), result in very low DIN-concentrations in lakes during the early summer (May to June). Therefore, the observed early summer DIN-concentrations in unproductive Swedish lakes (Table 2, Fig. 2) match the spatial pattern of wet DIN-deposition (Bergström et al. 2005), boosted by hydrological differences across the deposition gradient. For these reasons, lakes in southern Sweden have far higher DIN: $\mathrm{P}_{\text {Tot }}$ ratios during the early stratification period than lakes in the north.

Elevated lake DIN-concentrations in southern Sweden (Regions 1 and 2) caused eutrophication, as shown by the increase in chl a: $\mathrm{P}_{\text {Tot }}$ ratios (Table 1) (Bergström et al. 2005, Bergström \& Jansson 2006) and DIN-assimilation by phytoplankton. This contributed, in turn, to a decrease in lake DIN-concentrations. However, the DIN-decline was probably related to other processes as well, such as denitrification and outlet losses. The importance of hydrology was evident from the high seasonal variations in DIN-concentrations in small streams and lakes. Furthermore, this seasonal variation was particularly pronounced in south- ern Sweden (Regions 1 and 2), where lowered stream concentrations were followed by decreased lake concentrations (Fig. 2). It is not possible to derive quantitative estimates of the relative importance of processes responsible for DIN-losses (e.g. biological uptake, dissimilatory nitrate reduction, and various abiotic processes) from our data. However, Molot \& Dillon (1993) reported that $\sim 20 \%$ of the annual bulk atmospheric N-deposition (wet DIN-deposition: $\sim 900 \mathrm{~kg} \mathrm{~N} \mathrm{~km}^{-2} \mathrm{yr}^{-1}$ ) on forested catchments in Ontario was exported downstream from lakes, whereas losses due to sedimentation and denitrification were lower (4 and $12 \%$, respectively). The co-variation between stream and lake DIN indicates that stream water characteristics and lake water renewal times were also important determinants of lake DIN-concentrations in the present study. Consequently, hydrology probably had a greater influence on nutrient limitation than biological processes in small lakes with short water renewal times (1 to $3 \mathrm{mo}$ ).

Due to the geographical and seasonal variations in lake DIN concentrations and DIN: $\mathrm{P}_{\text {Tot }}$ ratios, the mean degrees of $\mathrm{N}$ - and P-limitation clearly differed between regions over the entire summer period. Nevertheless, in accordance with previously reported findings (Jansson et al. 1996, 2001, Bergström et al. 2005, Karlsson et al. 2005), single nutrient limitation by $\mathrm{N}$ was the natural state for lakes under low N-deposition (northern Sweden). In addition, the mean degree of Plimitation increased along the N-deposition gradient, directly reflecting the relative increase in DIN-availability in the southern, high-deposition areas (Regions 1 and 2). However, the mean degree of N-limitation was still higher than the mean degree of P-limitation in those areas over the summer season (Fig. 6).

There was also an increase in chl a responses, relative to control treatments, after $\mathrm{N}+\mathrm{P}$-additions, implying that phytoplankton became more nutrient limited over the summer. More severe nutrient limitations could be caused by decreasing pools of available limiting nutrients, or higher phytoplankton growth rates induced by increased lake water temperatures during late summer (Kalff 2002). Therefore, our results are in partial agreement with those from a global analysis of nutrient limitations of primary producers presented by Elser et al. (2007), showing that there are positive synergistic effects of combined $\mathrm{N}+\mathrm{P}$-enrichments in the pelagic zone of lakes, and that single nutrient enrichment by either $\mathrm{N}$ or $\mathrm{P}$ most likely induces limitation by the other element. On the other hand, our results differed in this respect from the study by Elser et al. (2007), since our studied lakes showed different growth responses to $\mathrm{N}$ - and P-enrichment alone (related to $\mathrm{N}$-deposition rates and $\mathrm{DIN}: \mathrm{P}_{\text {Tot }}$ ratios of the lakes). In addition, N-limitation was clearly more 
pronounced, and both spatially and temporally more widespread, than P-limitation.

Previous studies have shown that increases in the abundance of $\mathrm{N}_{2}$-fixing cyanobacteria can compensate for N-limitation of phytoplankton in productive lakes (Schindler 1977, Schindler et al. 2008). This kind of ecosystem response might not be detected in shortterm enclosure experiments such as ours, since $\mathrm{N}_{2}$ fixing cyanobacteria are slow-growing organisms (Chan et al. 2004). However, increases in the abundance of $\mathrm{N}$-fixing cyanobacteria are not a universal response to N-limitation. Unproductive lakes of northern Sweden have a naturally low abundance of $\mathrm{N}$-fixing cyanobacteria, and dense populations of cyanobacteria do not develop even though N-limited conditions prevail throughout the summer season (Holmgren 1983, Jansson et al. 1996, 2001). Moreover, dense populations of cyanobacteria do not develop in naturally N-limited unproductive lakes in northern Sweden, even under extremely N-limited conditions induced by $\mathrm{P}$-enrichment in whole-lake continuous $\mathrm{P}$ addition experiments over the summer (Jansson et al. 2001). Overall, this indicates that N-limitation does not necessarily induce $\mathrm{N}_{2}$-fixation in planktonic communities of unproductive lakes.

In summary, we showed that N-limitation of phytoplankton dominated in low atmospheric N-deposition areas in boreal Swedish lakes. P-limitation was observed during a relatively short period in the early summer in lakes in southern Sweden, where it was induced by high atmospheric N-deposition, high DINinputs via catchment runoff, and consequently high DIN-concentrations in the lakes. As the summer progressed, P-limitation in these systems switched to dual- and co-limitation of $\mathrm{N}$ and $\mathrm{P}$, and to N-limitation, due to exhaustion of the DIN-pool in the lakes.

Acknowledgements. We thank Jan Johansson at the Evolutionary Biology Centre, section of Limnology, Uppsala University, for running the nutrient analyses. We also thank Anna Sjöstedt, Grete Algesten, Ulf Westerlund, Renate Zindel, Carolyn Faithfull, Roger Nyman, and Ida Wanhatalo for field work assistance. This study was funded by the Swedish Research Council for Environment, Agricultural Sciences, and Spatial Planning.

\section{LITERATURE CITED}

Axler RP, Rose C, Tikkanen CA (1994) Phytoplankton nutrient deficiency as related to atmospheric nitrogen deposition in northern Minnesota acid-sensitive lakes. Can J Fish Aquat Sci 51:1281-1296

Baron JS, Rueth HM, Wolfe AM and others (2000) Ecosystem responses to nitrogen deposition in the Colorado Front Range. Ecosystems 3:352-368

Bergström AK, Jansson M (2000) Bacterioplankton production in humic Lake Örträsket in relation to input of bacter- ial cells and input of allochthonous organic carbon. Microb Ecol 39:101-115

Bergström AK, Jansson M (2006) Atmospheric nitrogen deposition has caused nitrogen enrichment and eutrophication of lakes in the northern hemisphere. Glob Change Biol 12:635-643

Bergström AK, Blomqvist P, Jansson M (2005) Effects of nitrogen deposition on nutrient limitation and phytoplankton biomass in unproductive Swedish lakes. Limnol Oceanogr 50:987-994

> Binkley D, Högberg P (1997) Does atmospheric deposition of nitrogen threaten Swedish forests? For Ecol Manag 92: $119-152$

> Bryhn AC, Blenckner T (2007) Can nitrogen gas be deficient for nitrogen fixation in lakes? Ecol Model 202:362-372

> Bukaveckas PA, Robbins-Forbes M (2000) Role of dissolved organic carbon in the attenuation of photosynthetically active and ultraviolet radiation in Adirondack lakes. Freshw Biol 43:339-354

Chan F, Pace ML, Howarth RW, Marino RM (2004) Bloom formation in heterocystic nitrogen-fixing cyanobacteria: the dependence on colony size and zooplankton grazing. Limnol Oceanogr 49:2171-2178

Elser JJ, Marzolf ER, Goldman CR (1990) Phosphorus and nitrogen limitation of phytoplankton growth in the freshwaters of North America: a review and critique of experimental experiments. Can J Fish Aquat Sci 47:1468-1477

Elser JJ, Bracken MES, Cleland EE and others (2007) Global analysis of nitrogen and phosphorus limitation of primary producers in freshwater, marine and terrestrial ecosystems. Ecol Lett 10:1135-1142

Galloway JN, Cowling EB (2002) Reactive nitrogen and the world: two hundred years of change. Ambio 31:64-71

> Holland EA, Braswell BH, Sulzman J and others (2005) Nitrogen deposition onto the United States and western Europe: synthesis of observations and models. Ecol Appl 15:38-57

Holmgren S (1983) Phytoplankton biomass and algal composition in natural fertilized and polluted subarctic lakes. $\mathrm{PhD}$ thesis, University of Uppsala, Uppsala

Howarth RW, Marino R (2006) Nitrogen as the limiting nutrient for eutrophication in coastal marine ecosystems: evolving views of three decades. Limnol Oceanogr 51:364-376

Jansson M, Blomqvist P, Jonsson A, Bergström AK (1996) Nutrient limitation of bacterioplankton, autotrophic and mixotrophic phytoplankton and heterotrophic nanoflagellates in Lake Örträsket, a large humic lake in northern Sweden. Limnol Oceanogr 41:1552-1559

Jansson M, Bergström AK, Drakare S, Blomqvist P (2001) Nutrient limitation of bacterioplankton and phytoplankton in humic lakes in northern Sweden. Freshw Biol 46: 653-666

Jansson M, Bergström AK, Lymer D, Vrede K, Karlsson J (2006) Bacterioplankton growth and nutrient use efficiencies under variable organic carbon and inorganic phosphorus ratios. Microb Ecol 52:358-364

Kalff J (2002) Limnology - inland water ecosystems. Prentice-Hall, Engelwood Cliffs, NJ

Karlsson J, Jonsson A, Jansson M (2005) Productivity of highlatitude lakes: climate effect inferred from altitude gradient. Glob Change Biol 11:710-715

> Koch RW, Guelda DL, Bukaveckas PA (2004) Phytoplankton growth in the Ohio, Cumberland and Tennessee Rivers, USA: inter-site differences in light and nutrient limitation. Aquat Ecol 38:17-26

Meili M (1992) Sources, concentrations and characteristics of organic matter in softwater lakes and streams of the 
Swedish forest region. Hydrobiologia 229:23-41

Molot LA, Dillon P (1993) Nitrogen mass balances and denitrification rates in central Ontario lakes. Biogeochemistry 20:195-212

Morris DP, Lewis W (1988) Phytoplankton nutrient limitation in Colorado mountain lakes. Freshw Biol 20:315-327

Raab B, Vedin H (1995) Climate, lakes and rivers - national atlas of Sweden. SNA Förlag, Stockholm

Ramberg L (1979) Relationships between phytoplankton and light climate in two Swedish forests lakes. Int Rev Gesamten Hydrobiol 64:749-782

Schindler DW (1977) Evolution of phosphorus limitation in lakes. Science 195:260-262

Schindler DW (1998) Replication versus realism: the need for ecosystem-scale experiments. Ecosystems 1:323-334

Schindler DW, Hecky RE, Findlay DL and others (2008) Eutrophication of lakes cannot be controlled by reduced nitrogen input: reults of a 37-year whole-ecosystem experiment. Proc Natl Acad Sci USA 105:11254-11258

Sobek S, Algesten G, Bergström AK, Jansson M, Tranvik LJ (2003) The catchment and climate regulation of $\mathrm{pCO}_{2}$ in

Editorial responsibility: Jonathan Cole, Millbrook, New York, USA boreal lakes. Glob Change Biol 9:630-641

Steffen W, Sanderson A, Tyson PD and others (2004) Global change and the earth system. Springer, Berlin

Vitousek PM, Aber JD, Howarth RW and others (1997) Human alteration of the global nitrogen cycle: sources and consequences. Ecol Appl 7:737-750

Wetzel RG (2001) Limnology - lake and river ecosystems. Academic Press, San Diego, CA

Wolfe AP, Baron JS, Cornett RJ (2001) Anthropogenic nitrogen deposition induces rapid ecological changes in alpine lakes of the Colorado Front Range (USA). J Paleolimnol $25: 1-7$

> Wolfe AP, Kaushal SS, Fulton JR, McKnight DM (2002) Spectrofluorescence of lake sediment fulvic acids and historical changes of lacustrine organic matter provenance in response to atmospheric nutrient enrichment. Environ Sci Technol 36:3217-3223

> Wolfe AP, Cooke CA, Hobbs WO (2006) Are current rates of atmospheric nitrogen deposition influencing lakes in the eastern Canadian Arctic? Arct Antarct Alp Res 38: $465-476$

Submitted: February 12, 2008; Accepted: October 6, 2008 Proofs received from author(s): October, 302008 